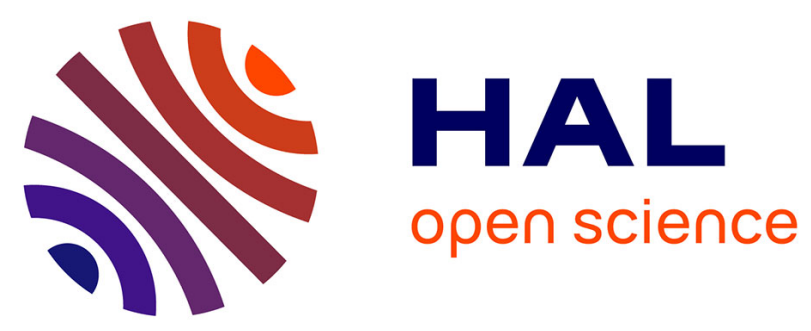

\title{
The genomic structure of strains isolated from marine mammals gives clues to evolutionary history within the genus
}

Gisèle Bourg, David O'Callaghan, Maria Laura Boschiroli

\section{- To cite this version:}

Gisèle Bourg, David O'Callaghan, Maria Laura Boschiroli. The genomic structure of strains isolated from marine mammals gives clues to evolutionary history within the genus. Veterinary Microbiology, 2007, 125 (3-4), pp.375. 10.1016/j.vetmic.2007.06.002 . hal-00532274

\section{HAL Id: hal-00532274 \\ https://hal.science/hal-00532274}

Submitted on 4 Nov 2010

HAL is a multi-disciplinary open access archive for the deposit and dissemination of scientific research documents, whether they are published or not. The documents may come from teaching and research institutions in France or abroad, or from public or private research centers.
L'archive ouverte pluridisciplinaire HAL, est destinée au dépôt et à la diffusion de documents scientifiques de niveau recherche, publiés ou non, émanant des établissements d'enseignement et de recherche français ou étrangers, des laboratoires publics ou privés. 


\section{Accepted Manuscript}

Title: The genomic structure of Brucella strains isolated from marine mammals gives clues to evolutionary history within the genus

Authors: Gisèle Bourg, David O’Callaghan, Maria Laura Boschiroli

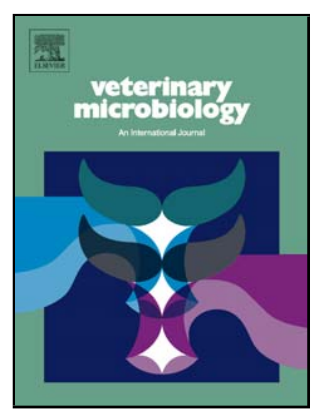

PII: S0378-1135(07)00303-3

DOI: doi:10.1016/j.vetmic.2007.06.002

Reference: VETMIC 3726

To appear in: $\quad$ VETMIC

Received date: $\quad 25-4-2007$

Revised date: $\quad 30-5-2007$

Accepted date: $\quad$ 4-6-2007

Please cite this article as: Bourg, G., O'Callaghan, D., Boschiroli, M.L., The genomic structure of Brucella strains isolated from marine mammals gives clues to evolutionary history within the genus, Veterinary Microbiology (2007), doi:10.1016/j.vetmic.2007.06.002

This is a PDF file of an unedited manuscript that has been accepted for publication. As a service to our customers we are providing this early version of the manuscript. The manuscript will undergo copyediting, typesetting, and review of the resulting proof before it is published in its final form. Please note that during the production process errors may be discovered which could affect the content, and all legal disclaimers that apply to the journal pertain. 
The genomic structure of Brucella strains isolated from marine mammals gives clues to evolutionary history within the genus.

\section{Gisèle Bourg, David O'Callaghan ${ }^{1}$ and Maria Laura Boschiroli ${ }^{2}$}

Institut National de la Santé et de la Recherche Médicale, ESPRI 26, UFR de Médecine, CS 83021, Avenue J.F. Kennedy, 30908 NIMES Cedex 02, France

${ }^{1}$ Corresponding author: Institut National de la Santé et de la Recherche Médicale, ESPRI 26, UFR de Médecine, CS 83021, Avenue J.F. Kennedy, 30908 NIMES Cedex 02, France. Tel : 33466028146 ; Fax : 33466028148 ;

E mail: david.ocallaghan@univ-montp1.fr

${ }^{2}$ Current address: Unité Zoonoses Bactériennes, Agence Française de Sécurité Sanitaire des Aliments, 23 av. du Général de Gaulle, 94706 Maisons-Alfort cedex, France 


\section{Abstract}

2 The genomic structure and the restriction maps were studied in 24 Brucella strains isolated

3 from marine mammals. From SpeI restriction profiles, the strains could be ascribed to three

4 clonal groups, each corresponding to a specific host. Cross contamination between

5 exclusively terrestrial and exclusively marine hosts is unlikely suggesting the divergence of

6 the different species of the genus Brucella may have taken place 60 million years ago,

7 concomitant with the radiation of their mammalian hosts (Artiodactyla) from other

8 mammalian orders.

10 Key words: Brucella; genomic organisation; physical map; evolution; marine mammal;

11 PFGE

\section{1. Introduction}

14 Brucella is a small Gram negative bacterium usually isolated from ruminants, pigs and

15 rodents. Classically the genus is divided into six species which are further subdivided into

16 several biovars, each infecting a preferential but not exclusive host (Boschiroli et al., 2001).

17 From the mid 1990s Brucella-like bacteria were isolated from carcas ses of marine mammals,

18 such as seals, dolphins, porpoises and whales. These bacteria have been found in a wide

19 range of tissues and have been shown to cause both abortion and meningoencephalitis (Foster

20 et al., 2002; Ohishi et al., 2003; Miller et al., 1999; Gonzalez et al., 2002) however very few

21 human infections have been reported (Sohn et al., 2003; Brew et al., 1999; McDonald et al.,

22 2006). These strains isolated form marine mammals could not be ascribed to the known six

23 species based on classical typing methods but could, however, be subdivided into three

24 groups based on $\mathrm{CO}_{2}$ dependence, galactose oxidation, dominant antigen and animal host

25 (Jahans et al., 1997). 
Over the past few years, molecular analysis using DNA/DNA hybridization and

27 ribotyping (Verger et al., 2000), genomic fingerprinting of Xba 1 profiles using PFGE (Jen sen

28 et al., 1999), analysis of insertion sequence profiles (Cloeckaert et al., 2000) and DNA

29 polymorphism in outer membrane protein genes (Cloeckaert et al., 2001a; Vizcaino et al.,

30 2004), has confirmed that the marine strains are gen etically distinct from the terrestrial strains

31 and, therefore, two new species, Brucella pinnipediae (group I strains) and Brucella cetaceae

32 (group II and III strains) have been proposed (Cloeckaert et al., 2001b). However, these

33 names have not yet been validly published and there remains some debate about the genetic

34 relationships within this group. Here we present the physical maps of the genomes of three

35 representative strains of marine Brucella which suggest that the group II and III strains

36 represent two distinct species.

\section{$38 \quad 2$ Materials and Methods}

\section{$39 \quad 2.1$ Bacterial Strains}

40 The Brucella strains used in this study and their hosts are listed in Table 1. Isolates were from 41 seals, dolphins, porpoises, an otter and a minke whale (Jahans et al., 1997; Clavareau et al., 42 1998).

\section{$44 \quad 2.2$ Pulsed Field Gel Electrophoresis}

45 PFGE was performed as previously described (Jumas-Bilak et al., 1995; Michaux-Charachon 46 et al., 1997). Briefly, intact genomic DNA was prepared from bacterial embedded in agarose 47 plugs and subjected to PFGE (BioRad CHEF DRII), either undigested or after digestion with $48 P a c \mathrm{I}$ or SpeI. Pulse conditions are described in figure legends. 


\subsection{Phylogenetic Analys is}

50 Similarity between strains was calculated as the Dice coefficient as described by Grothues

51 and Tummler (Grothues and Tummler, 1991) and clustered using the Phylip programme.

\section{3. Results and Discussion}

$54 \quad 3.1$ Restriction fragment le ngth polymorphism (RFLP) with in marine Brucella strain s.

55 The genomes of Brucella marine strains contain two chromosomes with sizes of about 2.1

$56 \mathrm{Mb}$ and $1.15 \mathrm{Mb}$, similar to that of the reference strain of the genus, B. melitensis $16 \mathrm{M}$ (data

57 not shown). The macrorestriction profiles obtained for genomic DNA digested by SpeI are

58 shown in Fig. 1. The restriction patterns fell into three groups that were identical to the

59 groups defined by Jahans et al (Jahans et al., 1997) based on classical typing methods. The

60 group I pattern was found in strains isolated from common, grey and hooded seals, and an

61 otter, group II pattern in strains isolated from common and striped dolphins and group III

62 pattern in strains isolated from porpoises, a white-sided dolphin and a mink whale. One 182

$63 \mathrm{~kb}$ fragment was missing from two group I strains (39-94 and 44-94; isolated from common

64 seals). Strain 56-94 (isolated from a hooded seal) shows the most divergence from the group

65 as it lacks the $182 \mathrm{~kb}$ fragment, a $62 \mathrm{~kb}$ and has other minor differences in the $20-30 \mathrm{~kb}$

66 region. The $62 \mathrm{~kb}$ fragment missing from strain 56-94 is specific to group I strains, since it

67 failed to hybridize with genomic DNA from any of the classical Brucella species or other

68 marine mammal strains (not shown). Comparison of the published Brucella genome

69 sequences (Paulsen et al., 2002; Halling et al., 2005; DelVecchio et al., 2002) suggests that

70 such species specific regions are rare in the genus, however, we have previously reported a

$7134 \mathrm{~kb}$ Spe1 fragment specific to B. ovis (Michaux-Charachon et al., 1997). Digestion of the

72 genomic DNA of the same strains by $X b a \mathrm{I}$ gives a similar strain grouping (Jensen et al., 
73 1999). In group II strains, an inversion in the large chromosome (see below) has increased

74 the size of the $330 \mathrm{~kb}$ fragment to $390 \mathrm{~kb}$ in strain $5-94$.

76 3.2 Restriction mapping of the Brucella marine isolates. The PacI and SpeI restriction

77 maps and localization of $r r n$ loci and insertion sequences were determined as described

78 previously (Michaux-Charachon et al., 1997; Jumas-Bilak et al., 1998). The maps are shown

79 in Fig. 2, together with the previously published map of B. melitensis 16M (Michaux-

80 Charachon et al., 1997). The location of the restriction sites on the large chromosome of the

81 marine strain shows few modifications when compared to that of B. melitensis. In a dolphin

82 isolate, strain 5-94, there is a large inversion of at least $550 \mathrm{~kb}$ in the large chromosome.

83 This rearrangement was first suggested by our observation that the $305 \mathrm{~kb}$ and $420 \mathrm{~kb}$ SpeI

84 fragments from $B$. melitensis both hybridized with the $390 \mathrm{~kb}$ and $260 \mathrm{~kb}$ SpeI fragments of

85 strain 5-94. The two fragments flanking the inversion contain copies of IS6501IS711,

86 suggesting a possible role for the insertion sequence in the rearrangement. On the contrary,

87 the maps of the small chromosome differed greatly from one strain to another, with numerous

88 indels (including the $62 \mathrm{~kb} \mathrm{SpeI}$ fragment unique to the seal isolates) and/or with creation or

89 loss of restriction sites. The reason for this observation is unknown. All the strains contained

90 three $r r n$ loci, two in the large chromosome and one in the small.

92 3.3 Phylogenetic analysis of the marine Brucella isolates. A phylogenetic tree (Fig. 3) was

93 obtained from the restriction data to complete the tree proposed previously (Michaux-

94 Charachon et al., 1997). The tree is unrooted, since the macrorestriction patterns are very

95 specific for Brucella and definition of a related extra group to place the root is artificial. The

96 marine isolates form a new group, which originates very near the $B$. ovis branch. Within this

97 group, the three clones are separated from each other by branches that are deeper than those 
98 between members of the melitensis-abortus group or the suis group. This suggest a probable

99 ancient divergence of the three restriction groups described within the marine isolates.

101 3.4 Evolutionary history of the Brucella genus The genus Brucella was proposed to be 102 monospecific based on the high levels of homology revealed by DNA-DNA hybridization 103 (Verger et al., 1985). This, however, does not reflect the 'classical' classification based on 104 phenotypic characteristics and host specificity and recently the 'classical' system has been 105 readopted. Since Brucella grow poorly in the environment and since each species infects a 106 preferential host, we and others proposed that each species is an evolutionary line adap ted to 107 a particular mammalian host (Michaux-Charachon et al., 1997; Moreno et al., 2002;

108 Michaux-Charachon et al., 2002). It has been proposed that B. suis is the closest to the 109 common ancestor of the genus (Moreno et al., 2002; Jumas-Bilak et al., 1998). Recent 110 investigation of the distribution of a $18.3 \mathrm{~kb}$ genomic island inserted downstream of gua A 111 supports this theory, being present in the genomes of B. suis, B. neotomae and the marine 112 strains, but not B. ovis, B. abortus and B. melitensis (Lavigne et al., 2005). Interestingly, 113 three point mutations in the $23 \mathrm{~S} r r n$ gene group the marine strains with B. melitensis, B. ovis 114 and B. neotomae (Halling and Jensen, 2006), giving rise to the question of whether the loss of 115 the incP island occurred once or at different times during the evolution of the genus. The 116 divergence could be concomitant either with the radiation of mammalian species, since each 117 natural host harbors a particular clone, or with the emergence of domestication, allowing 118 cross-contamination by close contact of different an imal species. The phylogeny of the 119 marine strains supports arguments for a divergence of the Brucella strains concomitant with 120 the radiation of mammals, since each of the different hosts is infected by a specific clone and 121 cross contamination between exclusively terrestrial and exclusively marine hosts is unlikely. 122 Moreno et al (Moreno et al., 2002) have suggested that B. abortus and B. melitensis became 
123 isolated about 20 million years ago with the radiation of the artiodactyls. This isolation could

124 be more ancient, since seals and otters belong to the order of Carnivora, which diverged from

125 the Artiod actyla more than 60 million years ago, and since wild rodents, another anciently

126 isolated order, are natural hosts for B. suis. However, a cross-contamination cannot be

127 excluded in this last case, rodents and wild pigs having similar territories. Finally, our results

128 further high light how the results of the classical typing methods reflect the groups defined by

129 genome organization. From the tree in Fig 3 (where the length of a branch is represents

130 evolutionary distance), we divergence between the three marine groups is far greater than that

131 between, for example, B. melitensis and B. abortus, suggesting that the three groups could

132 each be classified as a separate species. Further, recent data from both VNTR and MLST

133 typing also suggest that the strains can be divided into three groups (A Whatmore, personal

134 communication). These data are compatible with the proposition in the latest Bergey's

135 Manual of three new species; B. phocae (seals), B. phoecoenae (porpo ises) and B. delphini

136 (dolphins) (Corbel and Banai, 2005). Determination of the complete genome sequences of

137 these, and more Brucella strains is the next step in deciphering their evolutionary history.

139 4. Acknowledgments

140 We thank Alistair Macmillan, Bruno Garin-Bastuji and Jacques Godfroid for providing

141 Brucella strains. We thank Michel Ramuz for guidance and encouragement throughout this

142 work. Maria Laura Boschiroli was supported by fellowships from, CONICET and the UNU-

143 BIOLAC. Work in our laboratory is supported by INSERM, the European Community

144 (QLK2-CT-2001-01200), Université de Montpellier 1 (BQR), La Region Languedoc

145 Roussillon and La Ville de Nimes. 


\section{References}

Boschiroli, M.L., Foulongne, V., and O'Callaghan, D. (2001) Brucellosis: a worldwide zoonosis. Curr Opin Microbiol 4: 58-64.

Brew, S.D., Perrett, L.L., Stack, J.A., MacMillan, A.P., and Staunton, N.J. (1999) Human exposure to Brucella recovered from a sea mammal. Vet Rec 144: 483.

Clavareau, C., Wellemans, V., Walravens, K., Tryland, M., Verger, J.M., Grayon, M. et al. (1998) Phenotypic and molecular characterization of a Brucella strain isolated from a minke whale (Balaenoptera acutorostrata). Microbiology 144 ( Pt 12): 32673273.

Cloeckaert, A., Grayon, M., and Grepinet, O. (2000) An IS711 element downstream of the bp26 gene is a specific marker of Brucella spp. isolated from marine mammals. Clin Diagn Lab Immunol 7: 835-839.

Cloeckaert, A., Verger, J.M., Grayon, M., Paquet, J.Y., Garin-Bastuji, B., Foster, G., and Godfroid, J. (2001b) Classification of Brucella spp. isolated from marine mammals by DNA polymorphism at the omp2 locus. Microbes Infect 3: 729-738.

Cloeckaert, A., Verger, J.M., Grayon, M., Paquet, J.Y., Garin-Bastuji, B., Foster, G., and Godfroid, J. (2001a) Classification of Brucella spp. isolated from marine mammals by DNA polymorphism at the omp2 locus. Microbes Infect 3: 729-738.

Corbel, M.J., and Banai, M. (2005) Genus I. Brucella Meyer and Shaw 1920, $173 \mathrm{AL}$. In Bergey's Manuel of Systematic Bacteriology. Vol 2. Brenner D.J, Krieg N.R, and Staley J.T (eds). Springer, pp. 370-386.

DelVecchio, V.G., Kapatral, V., Redkar, R.J., Patra, G., Mujer, C., Los, T. et al. (2002) The genome sequence of the facultative intracellular pathogen Brucella melitensis. Proc Natl Acad Sci U S A 99: 443-448.

Foster, G., MacMillan, A.P., Godfroid, J., Howie, F., Ross, H.M., Cloeckaert, A. et al. (2002) A review of Brucella sp. infection of sea mammals with particular emphasis on isolates from Scotland. Vet Microbiol 90: 563-580.

Gonzalez, L., Patterson, I.A., Reid, R.J., Foster, G., Barberan, M., Blasco, J.M. et al. (2002) Chronic meningoencephalitis associated with Brucella sp. infection in livestranded striped dolphins (Stenella coeruleoalba). J Comp Pathol 126: 147-152.

Grothues, D., and Tummler, B. (1991) New approaches in genome analysis by pulsed-field gel electrophoresis: application to the analysis of Pseudomonas species. Mol Microbiol 5: 2763-2776.

Halling, S.M., and Jensen, A.E. (2006) Intrinsic and selected resistance to antibiotics binding the ribosome: analyses of Brucella 23S rrn, L4, L22, EF-Tu1, EF-Tu2, efflux and phylogen etic implications. BMC Microbiol 6: 84.

Halling, S.M., Peterson-Burch, B.D., Bricker, B.J., Zuerner, R.L., Qing, Z., Li, L.L. et al. (2005) Completion of the genome sequence of Brucella abortus and comparison to 
the highly similar genomes of Brucella melitensis and Brucella suis. J Bacteriol 187: 2715-2726.

Jahans, K.L., Foster, G., and Broughton, E.S. (1997) The characterisation of Brucella strains isolated from marine mammals. Vet Microbiol 57: 373-382.

Jensen, A.E., Cheville, N.F., Tho en, C.O., MacMillan, A.P., and Miller, W.G. (1999) Genomic fingerprinting and development of a dendrogram for Brucella spp. isolated from seals, porpoises, and dolphins. J Vet Diagn Invest 11: 152-157.

Jumas-Bilak, E., Maugard, C., Michaux-Charachon, S., Allardet-Servent, A., Perrin, A., O'Callaghan, D., and Ramuz, M. (1995) Study of the organization of the genomes of Escherichia coli, Brucella melitensis and Agrobacterium tumefaciens by insertion of a unique restriction site. Microbiology 141 ( Pt 10): 2425-2432.

Jumas-Bilak, E., Michaux-Charachon, S., Bourg, G., O'Callaghan, D., and Ramuz, M. (1998) Differences in chromosome number and genome rearrangements in the genus Brucella. Mol Microbiol 27: 99-106.

Lavigne, J.P., Vergunst, A.C., Bourg, G., and O'Callaghan, D. The 'incP island' in the genome of Brucella suis 1330 was acquired by site specific integration. Infect.Immun. 2005.

Ref Type: Generic

McDonald, W.L., Jamaludin, R., Mackereth, G., Hansen, M., Humphrey, S., Short, P. et al. (2006) Characterization of a Brucella sp. strain as a marine-mammal type despite isolation from a patient with spinal osteomyelitis in New Zealand. $J$ Clin Microbiol 44: 4363-4370.

Michaux-Charachon, S., Bourg, G., Jumas-Bilak, E., Guigue-Talet, P., AllardetServent, A., O'Callaghan, D., and Ramuz, M. (1997) Genome structure and phylogeny in the genus Brucella. J Bacteriol 179: 3244-3249.

Michaux-Charachon, S., Jumas-Bilak, E., lardet-Servent, A., Bourg, G., Bosch iroli, M.L., Ramuz, M., and O'Callaghan, D. (2002) The Brucella genome at the beginning of the post-genomic era. Vet Microbiol 90: 581-585.

Miller, W.G., Adams, L.G., Ficht, T.A., Cheville, N.F., Payeur, J.P., Harley, D.R. et al. (1999) Brucella-induced abortions and infection in bottlenose dolphins (Tursiops truncatus). J Zoo Wildl Med 30: 100-110.

Moreno, E., Cloeckaert, A., and Moriyon, I. (2002) Brucella evolution and taxonomy. Vet Microbiol 90: 209-227.

Ohishi, K., Zenitani, R., Bando, T., Goto, Y., Uchida, K., Maruyama, T. et al. (2003) Pathological and serological evidence of Brucella-infection in baleen whales (Mysticeti) in the western North Pacific. Comp Immunol Microbiol Infect Dis 26: 125136.

Paulsen, I.T., Seshadri, R., Nelson, K.E., Eisen, J.A., Heidelberg, J.F., Read, T.D. et al. (2002) The Brucella suis genome reveals fundamental similarities between animal and plant pathogens and symbionts. Proc Natl Acad Sci U S A 99: 13148-13153. 
Sohn, A.H., Probert, W.S., Glaser, C.A., Gupta, N., Bollen, A.W., Wong, J.D. et al. (2003) Human neurobrucellosis with intracerebral granuloma caused by a marine mammal Brucella spp. Emerg Infect Dis 9: 485-488.

Verger, J.M., Grayon, M., Cloeckaert, A., Lefevre, M., Ageron, E., and Grimont, F. (2000) Classification of Brucella strains isolated from marine mammals using DNADNA hybridization and ribotyping. Res Microbiol 151: 797-799.

Verger, J.M., Grimont, F., Grimont, P.A., and Grayon, M. Brucella, a monospecific genus as shown by deoxyribonucleic acid hybridization. Int J Syst Bacteriol 35, 292295.

1985.

Ref Type: Generic

Vizcaino, N., Caro-Hernandez, P., Cloeckaert, A., and Fernandez-Lago, L. (2004) DNA polymorphism in the omp25/omp 31 family of Brucella spp.: identification of a 1.7-kb inversion in Brucella cetaceae and of a 15.1-kb genomic island, absent from Brucella ovis, related to the synthesis of smooth lipopolysaccharide. Microbes Infect 6: 821-834. 
Table 1. Brucella strains included in this study.

\begin{tabular}{lll}
\hline Brucella strain & Host & \\
& Vernacular name & Scientific name \\
\hline Group I* & Common seal & Phoca vitulina \\
$2-94$ & Common seal & Phoca vitulina \\
$40-94$ & Common seal & Phoca vitulina \\
$41-94$ & Common seal & Phoca vitulina \\
$48-94$ & Common seal & Phoca vitulina \\
$46-94$ & Common seal & Phoca vitulina \\
$54-94$ & Grey seal & Halicherus grypus \\
$61-94$ & Otter & Lutra lutra \\
$55-94$ & Common seal & Phoca vitulina \\
$39-94$ & Common seal & Phoca vitulina \\
$44-94$ & Hooded seal** & Cystophora cristata \\
$56-94$ & & \\
\hline Group II & Common dolphin & Delphinus delphis \\
$47-94$ & Common dolphin & Delphinus delphis \\
$14-94$ & Striped dolphin & Stenella coeruleoalba \\
$59-94$ & Striped dolphin & Stenella coeruleoalba \\
$5-94$ & & \\
\hline Group III & Mink whale & Balaenoptera acutorostrata \\
$202-\mathrm{R}$ & White-sided dolphin & Lagenorhynchus actus \\
$49-94$ & Harbour porpoise & Phocoena phocoena \\
$1-94$ & Harbour porpoise & Phocoena phocoena \\
$34-94$ & Harbour porpoise & Phocoena phocoena \\
$35-94$ & Harbour porpoise & Phocoena phocoena \\
$36-94$ & Harbour porpoise & Phocoena phocoena \\
$45-94$ & Harbour porpoise & Phocoena phocoena \\
$52-94$ & Harbour porpoise & Phocoena phocoena \\
$57-94$ & & \\
\hline & & \\
\hline & &
\end{tabular}

* Groups I, II and III contain strain s with a similar SpeI-restriction pattern .

** The SpeI profile of this isolate differs from the other strains included in this group by the absence of a $62 \mathrm{~kb}$ fragment. 


\section{Figure Legends}

Figure 1. Pulsed field gel electrophoresis of SpeI-digested DNA from Brucella marine isolates. SpeI fragments were separated in a contour clamped electric field apparatus (CHEF-DRII Biorad) with pulse ramps of $35 \mathrm{~s}-4 \mathrm{~s}$ for $40 \mathrm{~h}$ at $180 \mathrm{~V}$. The strains are organized as described in Table 1. $\lambda$ concatamer size markers are on the left of the figure. Patterns of SpeI-digests of B. melitensis 16M, B. abortus 544 and B. suis 1330 DNA are shown at the right. Arrowheads indicate bands migrating differently or absent.

Figure 2. SpeI-PacI restriction maps of the chromosomes of B. melitensis 16M, strains 59-94 and 5-94 (isolated from dolphins), 34-94 (isolated from a porpoise) and 2-94 (isolated from a seal). The two circular chromosomes are represented in linear form, each one starting from a conserved SpeI fragment. A: large chromosomes; B: small chromosomes. For each chromosome map, SpeI sites are located above, and PacI sites below. Sizes are given in kilobases for all the restriction fragments of the $B$. melitensis chromosomes, and only for those different from B. melitensis for the other species. Fragments carrying rrn loci are represented by open squares, and fragments carrying IS6501/IS711 copies by stars. The inversion in the large chromosome of strain 5-94 is shown by two broken lines.

Figure 3. Phylogenetic tree of the marine isolates and the different species and biovars of the genus Brucella (modified from (Boschiroli et al., 2001). The terrestrial strains are represented by the reference strains for each species and/or biovar using data from (Michaux-Charachon et al., 1997). B. abortus contains two major groups, represented by $\mathrm{Bv} 1$ and 5 , due to the $600 \mathrm{~kb}$ inversion in the small chromosome in certain strains. 


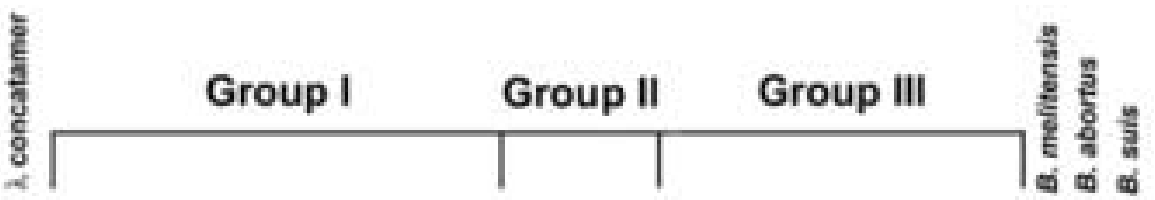

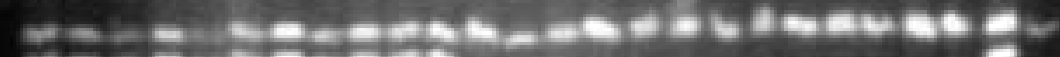

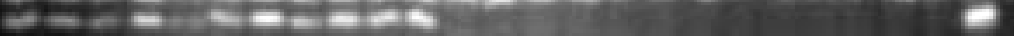

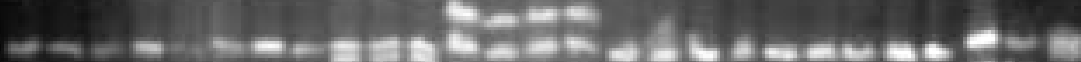

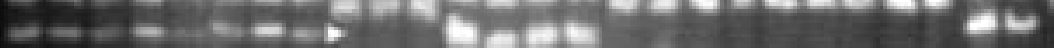

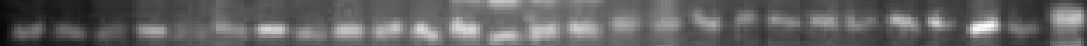

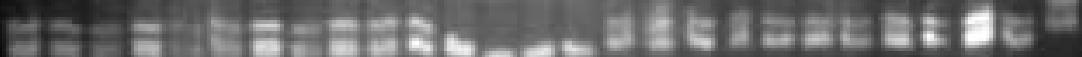

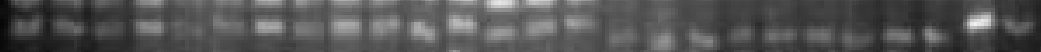

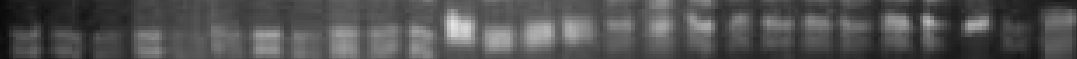

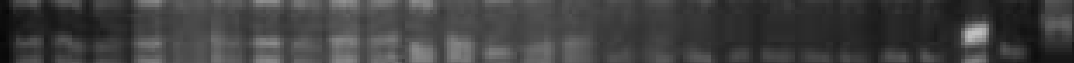

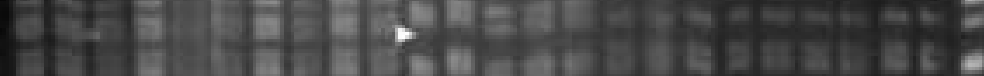


A

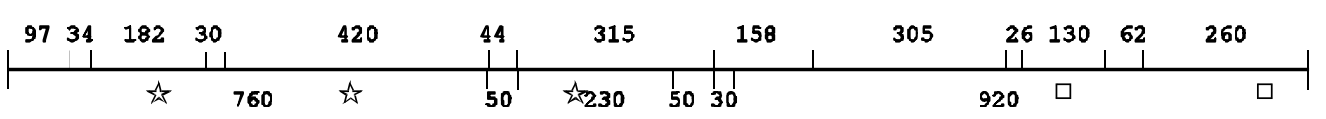

B. melitensis

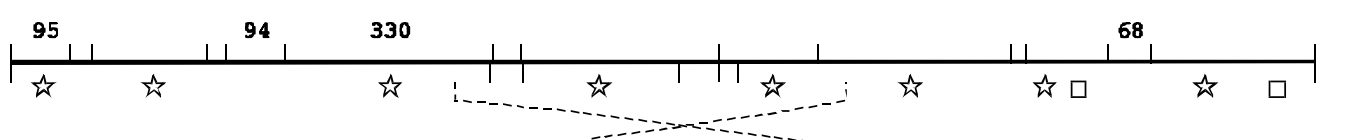

Strain 59-94 (dolphin)

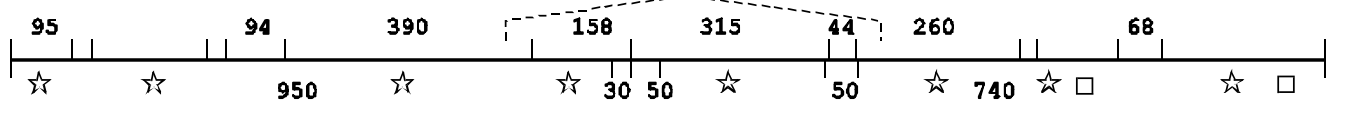

strain 5-94 (dolphin)

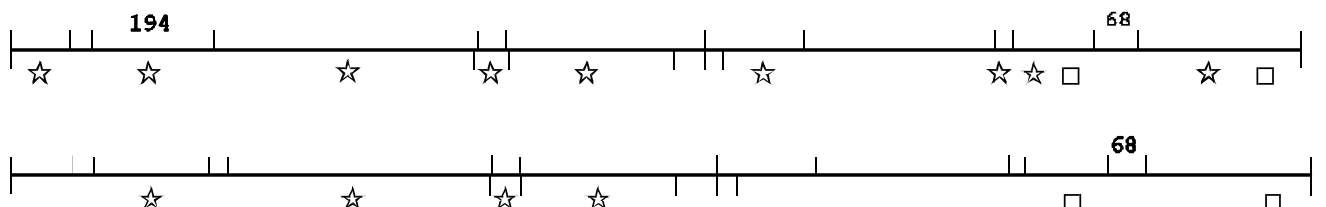

Strain 34-94 (porpolse) $\underset{\text { Strain }}{\text { (seal) }}$

B

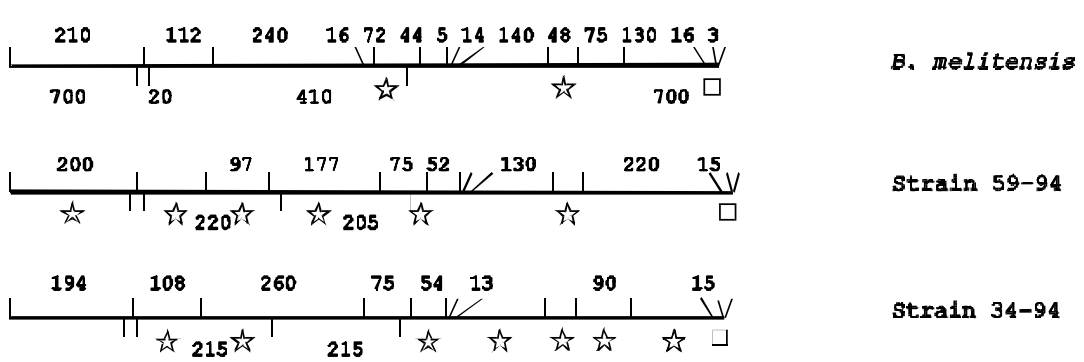

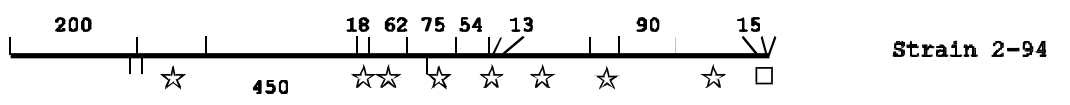




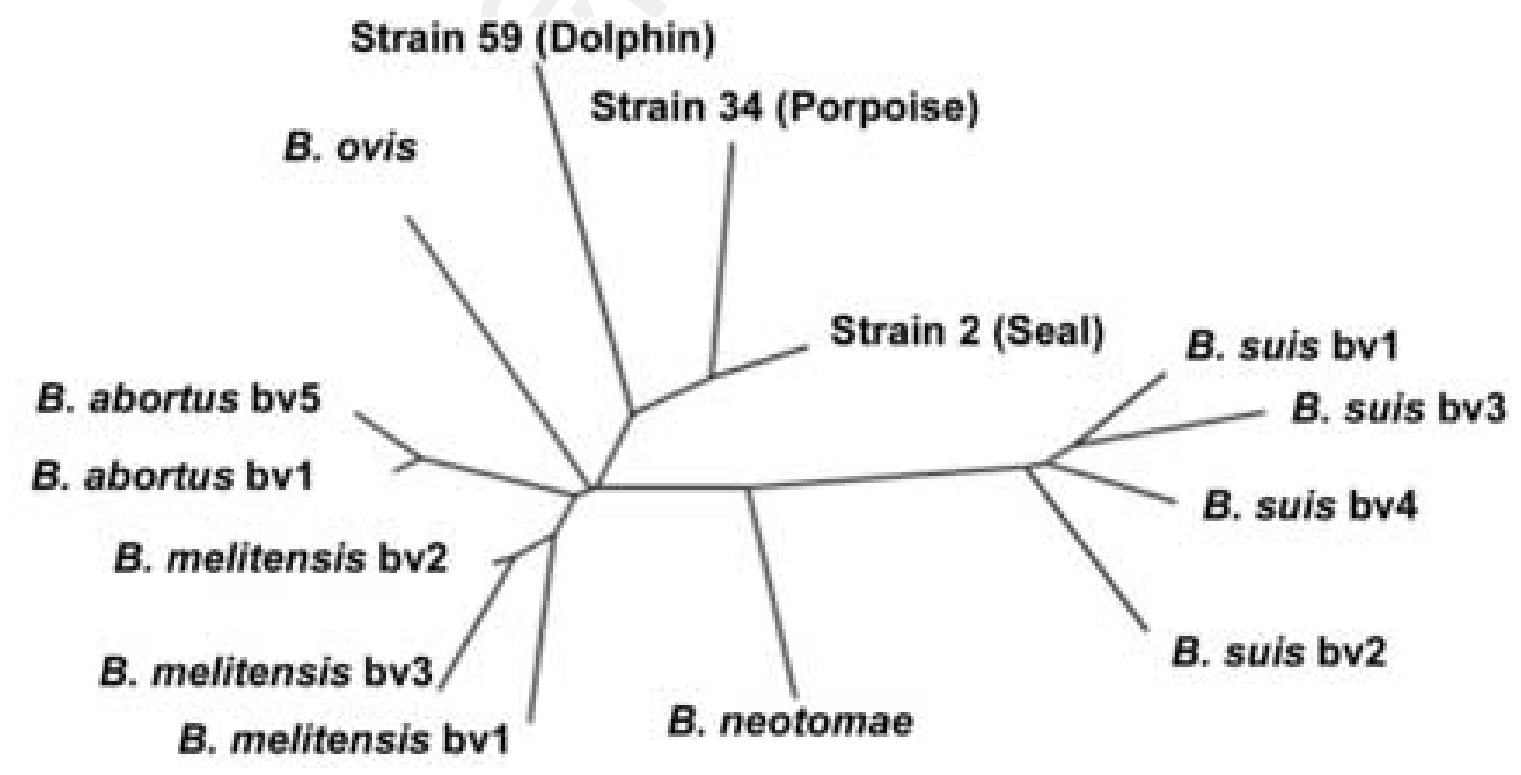

